\title{
Environmentally relevant concentrations of silver nanoparticles diminish soil microbial biomass but do not alter enzyme activities or microbial diversity
}

\author{
Gabriela Montes de Oca-Vásquez ${ }^{\mathrm{a}, \mathrm{b}, *}$, Frank Solano-Campos ${ }^{\mathrm{c}}$, José R. Vega-Baudrit ${ }^{\mathrm{a}, \mathrm{d}}$, \\ Rubén López-Mondéjar ${ }^{e}$, Iñaki Odriozola ${ }^{e}$, Alfonso Vera ${ }^{\mathrm{f}}$, José L. Moreno ${ }^{\mathrm{f}}$, Felipe Bastida ${ }^{\mathrm{f}}$ \\ ${ }^{a}$ National Nanotechnology Laboratory, National Center for High Technology, 10109 Pavas, San José, Costa Rica \\ ${ }^{\mathrm{b}}$ Doctorado en Ciencias Naturales para el Desarrollo (DOCINADE), Instituto Tecnológico de Costa Rica, Universidad Nacional, Universidad Estatal a Distancia, Costa Rica \\ ${ }^{\mathrm{c}}$ School of Biological Sciences, Universidad Nacional, Campus Omar Dengo, 86-3000 Heredia, Costa Rica \\ ${ }^{\mathrm{d}}$ Laboratory of Polymer Science and Technology, School of Chemistry, Universidad Nacional, Campus Omar Dengo, 86-3000 Heredia, Costa Rica \\ ${ }^{\mathrm{e}}$ Laboratory of Environmental Microbiology, Institute of Microbiology of the CAS, Vídeňská 1083, Praha 4 14220, Czech Republic \\ ${ }^{\mathrm{f}}$ CEBAS-CSIC. Department of Soil and Water Conservation, Campus Universitario de Espinardo, 30100, Murcia, Spain
}

\section{G R A P H I C A L A B S T R A C T}
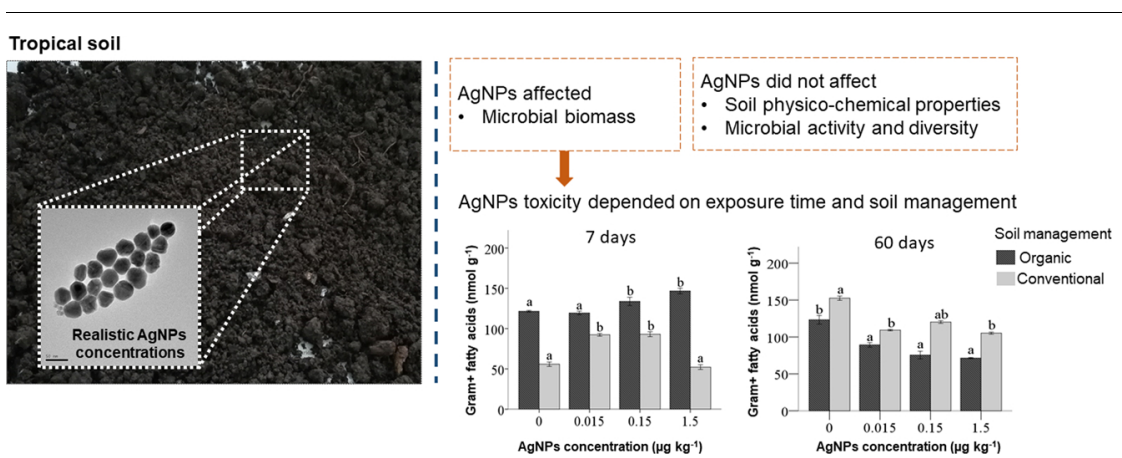

\section{A R T I C L E I N F O}

Editor: R. Debora

Keywords:

Ag nanoparticles

Soil microbial community

Enzyme activities

Biomass

\begin{abstract}
A B S T R A C T
The increasing use of silver nanoparticles (AgNPs) due to their well-known antimicrobial activity, has led to their accumulation in soil ecosystems. However, the impact of environmental realistic concentrations of AgNPs on the soil microbial community has been scarcely studied. In this work, we have assessed the impact of AgNPs, that mimic real concentrations in nature, on tropical soils cultivated with Coffea arabica under conventional and organic management systems. We evaluated the biomass, extracellular enzyme activities, and diversity of the soil microbial community, in a microcosm experiment as a function of time. After seven days of incubation, we found an increase in microbial biomass in an AgNPs-concentration-independent manner. In contrast, after 60-day-incubation, there was a decrease in Gram + and actinobacterial biomass, in both soils and all AgNPs concentrations. Soil physico-chemical properties and enzyme activities were not affected overall by AgNPs. Regarding the microbial community composition, only some differences in the relative abundance at phylum and genus level in the fungal community were observed. Our results suggest that environmental concentrations of AgNPs affected microbial biomass but had little impact on microbial diversity and may have little effects on the soil biogeochemical cycles mediated by extracellular enzyme activities.
\end{abstract}

\footnotetext{
*Corresponding author at: National Nanotechnology Laboratory, National Center for High Technology, 10109 Pavas, San José, Costa Rica.

E-mail address: gmontesdeoca@cenat.ac.cr (G. Montes de Oca-Vásquez).
} 


\section{Introduction}

The emergence of nanotechnology is concerning because there are now thousands of consumer products that contain nanoparticles (NPs), especially silver nanoparticles (AgNPs), one of the most commercialized nanomaterials worldwide, principally due to their antifungal and antibacterial properties (McGee et al., 2018). As such, nanoparticles are used in a wide variety of products, including textiles (Ballottin et al., 2017), cosmetics (Salvioni et al., 2017), medical devices (van Hengel et al., 2017) electronic devices (Matsuhisa et al., 2017), food (Kumar et al., 2018), and products for wastewater treatment (Bi et al., 2018). Owing to these uses, there are multiple points of entry of NPs into ecosystems, principally in soil, such as the use of biosolids as fertilizer (i.e., sludges and composts) (Wang et al., 2016; Kraas et al., 2017), application of AgNPs for plant growth promotion (Hänsch and Emmerling, 2010), and plant disease management (Haq and Ijaz, 2019).

Soil microbial communities play essential roles in ecosystem functioning, especially in the transformation and processing of nutrients in terrestrial ecosystems, soil fertility, and sustainability of the planet (Graham et al., 2016; Shen et al., 2016; Camenzind et al., 2018). For instance, soil microbial enzymes are deeply involved in the cycles of carbon (i.e. $\beta$-glucosidase), nitrogen (i.e. urease) and phosphorus (i.e. phosphatase), and are generally considered as indicators of soil quality (Bastida et al., 2008). It is known that soil microbial communities are sensitive to environmental stressors, potentially resulting in substantial impacts on biogeochemical processes and ecosystem function (Shen et al., 2016; McGee et al., 2017). However, in spite of their importance for the maintenance of ecosystem functions (Delgado-Baquerizo et al., 2016), little is known about the effect of AgNPs on the soil microbial community (Simonin and Richaume, 2015; Bundschuh et al., 2018; Grün et al., 2018). Recent studies suggest that AgNPs can accumulate in the soil environment and have toxic effects on the microbial communities (Beddow et al., 2017; Samarajeewa et al., 2017). Several authors have concluded that the toxic effects on microbial communities are highly dependent on the AgNPs concentration in the soil (Hänsch and Emmerling, 2010; Shin et al., 2012; Peyrot et al., 2014). However, most studies have evaluated AgNPs at higher levels than actually occur in nature (Rahmatpour et al., 2017; Storey and Doyle, 2017; Asadishad et al., 2018; Grün et al., 2018). Further, it has been demonstrated that the toxic effects on the soil microbial community are also highly dependent on both the NPs properties and the physico-chemical soil properties (Raffi and Husen, 2019; Grün et al., 2019). The chemical nature of the NPs along with their concentration, size, shape, surface chemistry, charge, and other spects seem to play an important role in the toxicity (Gottschalk et al., 2010; Schlich and Hund-Rinke, 2015; Grün et al., 2019). In soil, the texture, organic matter content, and $\mathrm{pH}$ have been suggested to play a role in the bioavailability of NPs (Schlich and Hund-Rinke, 2015; Rahmatpour et al., 2017; Grün et al., 2019).

Nowadays, there are probabilistic analyses to predict the concentrations of engineered AgNPs in agricultural soil, based on modeling studies (Giese et al., 2018). While there are studies that have addressed the impact of NPs in soil, they have been carried out mainly with high, non-realistic concentrations of NPs (Simonin and Richaume, 2015; Storey and Doyle, 2017; Arvidsson, 2018; Grün et al., 2018) - in the range of $0.1-1815 \mathrm{mg} \mathrm{kg}^{-1}$ (Peyrot et al., 2014; McKee and Filser, 2016; McGee et al., 2017; Samarajeewa et al., 2017) -. In contrast, predicted environmental concentrations of AgNPs in agricultural soils are in the range of $0.24-792.23 \mathrm{ng} \mathrm{kg}^{-1}$, with a maximum of $10 \mu \mathrm{g} \mathrm{kg}^{-1}$ predicted for 2050 (Giese et al., 2018). Since only a few studies have considered realistic concentrations of AgNPs (Bundschuh et al., 2018; Grün et al., 2018), more research should be carried out to address this matter more profoundly (Simonin and Richaume, 2015). Particularly, whether or not realistic NPs concentrations affect the diversity and functioning of soil microbial communities should be addressed (Bastida et al., 2008; Chung et al., 2011; Zornoza et al., 2015). Taking into consideration the importance of soil microbial communities for the maintenance of soil ecosystem services and the increasing release of NPs into the environment due to industrial development, the aim of this study was to reveal the effects of AgNPs, at realistic concentrations occurring in nature, on the biomass, activity, and diversity of the microbial community of a soil cultivated with Coffea arabica, grown for coffee consumption. In Costa Rica, coffee is one of the main export products with a cultivation area of 93,697 ha and a 2019-2020 harvest of more than 1.9 million bushels (Instituto del Café de Costa Rica, 2019).

To our knowledge, this is the first work evaluating the impact of environmental concentrations of AgNPs on a tropical agricultural soil, and under different management systems. Soil management can alter the diversity and composition of soil microbial communities (Smith et al., 2016; García-Delgado et al., 2019; Moreno et al., 2019) and soil microbial populations can differ in their resistance to AgNPs (Tlili et al., 2017; Asadishad et al., 2018; Grün et al., 2018). Hence, we hypothesized that soils subjected to different management (conventional vs organic) would have evolved different microbial communities (in terms of biomass, diversity, and activity) that differ in their sensitivity to silver nanoparticles at relevant concentrations found in nature.

\section{Materials and methods}

\subsection{Characterization of silver nanoparticles}

Citrate-coated AgNPs were purchased from Sigma-Aldrich (St. Louis, USA). According to the manufacturer, these AgNPs have a mean particle size of $40 \mathrm{~nm}$ in powder form, as measured by transmission electron microscopy (TEM). The particle size of an AgNPs suspension (1:3 dilution of commercial solution) was verified using TEM (JEOL, JEM2011), at an acceleration voltage of $120 \mathrm{kV}$ (Fig. S1. Supporting Information), previously to prepare the homogenous AgNPs suspensions applied to the microcosm. Samples were prepared by placing $5 \mu \mathrm{l}$ of the reaction mixtures on carbon-coated copper grids, followed by drying in a desiccator with silica for $16 \mathrm{~h}$.

In addition, the hydrodynamic diameter, zeta potential, and polydispersity of the AgNPs were determined by dynamic light scattering (DLS), using a Zetasizer Nano Zs90 instrument (Malvern Instruments, UK). The analyses were carried out with a dispersion angle of $90^{\circ}$, at a temperature of $25^{\circ} \mathrm{C}$, using samples diluted (1:3) with Milli-Q water (Fig. S2). The hydrodynamic diameter and zeta potential of AgNPs was $33.09 \pm 0.38 \mathrm{~nm}$ and $-32.5 \pm 3.34 \mathrm{mV}$, respectively.

\subsection{Study area}

Soils were collected at the Santa Lucía experimental farm - located in Santa Lucía, Barva, Heredia, Costa Rica (coordinates $10^{\circ} 01^{\prime} 19.5^{\prime \prime} \mathrm{N}$, $84^{\circ} 06^{\prime} 43.5^{\prime \prime} \mathrm{W}$ ) - and managed by Universidad Nacional. The climate in this area is classified as Tropical Monsoon, according to the KöppenGeiger climate classification, and the climax vegetation is characterized as a premontane wet forest, according to the Holdridge life zone system. The average annual temperature and precipitation are $21.5^{\circ} \mathrm{C}$ and $2371 \mathrm{~mm}$, respectively. The average elevation of the study area is 1159 m.a.s.l. The soil is principally of volcanic origin, and classified as andisols (FAO, 1988).

Within this experimental farm, Coffea arabica cv. Caturra was cultivated under a conventional management system (CMS) in an area of $8000 \mathrm{~m}^{2}$ in the three years prior collecting the samples, and under an organic management system (OMS) in an adjacent area of $8000 \mathrm{~m}^{2}$ in the 6 years prior collecting the samples. Three plots of $2000 \mathrm{~m}^{2}$ each for each type of management were established, giving a total of 6 plots. In this study, conventional and organic managements refer mainly to the fertilization, herbicides and fungicides utilized. Thus, the conventional management included fertilization with $780 \mathrm{~kg} \mathrm{ha}^{-1}$ of $\mathrm{N}, 1066 \mathrm{~kg}$ $\mathrm{ha}^{-1}$ of $\mathrm{P}_{2} \mathrm{O}_{5}$, and $453 \mathrm{~kg} \mathrm{ha}^{-1}$ of $\mathrm{K}_{2} \mathrm{O}$ per year, in addition to 
Table 1

Microbial biomass, enzyme activities and microbial diversity presents in CMS and OMS.

\begin{tabular}{lll}
\hline & CMS & OMS \\
\hline Biomass $\left(\mathbf{n m o l ~ g}^{-1}\right.$ ) & & \\
Fungal & $3.58 \pm 1.37$ & $17.46 \pm 3.80$ \\
Bacterial & $57.28 \pm 26.10$ & $143.04 \pm 9.62$ \\
Gram + & $44.73 \pm 22.32$ & $116.39 \pm 10.93$ \\
Gram- & $12.55 \pm 3.79$ & $26.66 \pm 9.06$ \\
Actinobacterial & $6.80 \pm 3.66$ & $18.83 \pm 2.11$ \\
Enzyme activities & & \\
$\beta$-Glucosidase $\left(\mu \mathrm{mol} \mathrm{PNP} \mathrm{g}{ }^{-1} \mathrm{~h}^{-1}\right)$ & $1.04 \pm 0.05$ & $1.38 \pm 0.03$ \\
Urease $\left(\mu\right.$ mol NH $\left.\mathrm{g}^{-1} \mathrm{~h}^{-1}\right)$ & $1.21 \pm 0.09$ & $1.57 \pm 0.05$ \\
Acid phosphatase $\left(\mu \mathrm{mol} \mathrm{PNP} \mathrm{g}^{-1} \mathrm{~h}^{-1}\right)$ & $12.44 \pm 0.64$ & $11.87 \pm 0.29$ \\
Microbial diversity & & \\
Fungal OTUs & $2623(1996)^{*}$ & $2700(2073)$ \\
Bacterial OTUs & $5176(2419)$ & $6576(3819)$ \\
\hline
\end{tabular}

*number in parenthesis indicate the soil type-specific OTUs.

bimonthly applications of herbicide (glyphosate) and fungicide (triazole compounds). The organic management consisted of alternated fertilization with green compost and chicken manure, at $1.5 \mathrm{~kg}$ of each per plant thrice a year, and mechanical weed control. Overall, there were no differences between the two soil management regimes in the soil total $\mathrm{N}$ and organic matter contents, $\mathrm{pH}$, electrical conductivity, or texture (Table S1). The microbial biomass, enzyme activities ( $\beta$-glucosidase, urease and acid phosphatase), and microbial diversity of operational taxonomic units (OTUs) presents in CMS and OMS are shown in Table 1.

\subsection{Soil microcosms and experimental design}

Twenty soil samples $(0-20 \mathrm{~cm}$ soil cores) were collected in each plot, covering the whole area. A composite soil sample of approximately $10 \mathrm{~kg}$ was obtained by mixing the 20 samples per plot, and was utilized for further microcosm assays. Large woody litter, such as branches, was removed from the soil samples, and the soil was dried at room temperature and sieved (2-mm mesh). The treatments were established in replicates $(n=3)$. For each regime (OMS and CMS), three different stock solutions were made in order to add the same volume ( $55 \mathrm{~mL}$ ) of the AgNPs suspension in all the soil samples, to obtain final concentrations of $0.015,0.15$, and $1.5 \mu \mathrm{g} \mathrm{kg}^{-1}$. Soils receiving the same volume of ultrapure water were used as controls. Three times of exposure to AgNPs (7, 30, and 60 days), were independently established. Homogeneous AgNPs suspension was added to $150 \mathrm{~g}$ of soil in $200-\mathrm{mL}$ containers and then extensively mixed by stirring with a spoon to obtain a uniform distribution. The microcosms were placed in random positions in a temperature-controlled $\left(28^{\circ} \mathrm{C}\right)$ chamber (LABNET 211 DS, Labnet International, US), in the dark. The water retention capacity was gravimetrically controlled at $60 \%$ throughout the incubation period. This experimental design resulted in a total of 72 microcosms, including 3 replicates per treatment ( 2 soil managements $\times 3$ concentrations of AgNPs $\times 3$ sampling times $\times 3$ replicates, plus controls). At the end of each incubation time, $3 \mathrm{~g}$ of soil from each microcosm were stored at $-20^{\circ} \mathrm{C}$ for up to 4 weeks for DNA extraction and the remaining sample was kept at $4{ }^{\circ} \mathrm{C}$ for further analysis of soil physicochemical properties, enzyme activities, and fatty acids.

\subsection{Physico-chemical analysis of soil samples}

After the AgNPs application, the electrical conductivity and $\mathrm{pH}$ were measured in a 1:5 (w:v) aqueous extract, with a conductivity meter and pH meter (Crison mod.2001, Barcelona, Spain), respectively. The total nitrogen content $(\mathrm{N})$ and total organic carbon (TOC) were determined using an elemental analyzer (C/N Flash EA 1112 Series-Leco Truspec). Aqueous extracts of soil were prepared with deionized water (1:5, w:v) by shaking for $2 \mathrm{~h}$, followed by centrifugation at $13.000 \mathrm{rpm}$ for $15 \mathrm{~min}$ and filtration. The water-soluble C (WSC) and N (WSN) contents in these extracts were determined in an analyzer for liquid samples (Multi N/C 3100, Analytik Jena).

\subsection{Microbial fatty acids and enzyme activities}

Ester-linked microbial fatty acids were extracted from $1 \mathrm{~g}$ of soil by chloroform-methanol extraction, as described by Schutter and Dick (2000). Fatty acids were quantified by gas chromatography (Trace GC Ultra, Thermo Scientific) using a $60 \mathrm{~m}$ capillary GC column (SGE Analytical Science, BPX70, $60 \mathrm{~m} \times 0.25 \mathrm{~mm}$ ID x0.25 $\mu \mathrm{m}$ film) and helium as the carrier gas. The initial temperature was $120^{\circ} \mathrm{C}$ for $0.5 \mathrm{~min}$, then it was increased to $140{ }^{\circ} \mathrm{C}$ with a ramp of $1{ }^{\circ} \mathrm{C} / \mathrm{min}$, then to $170^{\circ} \mathrm{C}$ with increments of $2{ }^{\circ} \mathrm{C} / \mathrm{min}$, and finally to $210^{\circ} \mathrm{C}$ at $2{ }^{\circ} \mathrm{C} / \mathrm{min}$. The fatty acids i15:0, a15:0, 15:0, i16:0, i17:0, 18:1 $9 \mathrm{t}$, and cy19:0 were representative of the bacterial biomass (Frostegård et al., 1993; Dungait

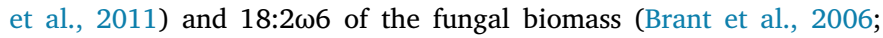
Rinnan and Bååth, 2009). The Gram-positive (G+) representative fatty acids were i15:0, a15:0, i16:0, and i17:0, and the Gram-negative (G-) representative fatty acid was cy19:0 (Frostegård et al., 1993; Dungait et al., 2011).

The urease activity in the soil was determined by the buffered method of Kandeler and Gerber (1988). Briefly, $0.5 \mathrm{~mL}$ of a solution of urea $(0.48 \%)$ and $4 \mathrm{~mL}$ of borate buffer $(\mathrm{pH} 10)$ were added to $1 \mathrm{~g}$ of soil and then incubated for $2 \mathrm{~h}$ at $37^{\circ} \mathrm{C}$. The ammonium concentration of the centrifuged extracts was determined by a modified indophenolblue reaction and measured at $690 \mathrm{~nm}$ by spectrophotometry, and expressed in units of micromoles of ammonium- $\mathrm{N}$ produced per gram of soil (dry weight) and hour ( $\mu \mathrm{mol} \mathrm{NH}_{4}-\mathrm{N} \mathrm{g}^{-1} \mathrm{~h}^{-1}$ ). The acid phosphatase (PA) and $\beta$-glucosidase (BA) activities were determined according to Tabatabai and Bremner (1969) and Eivazi and Tabatabai (1977), respectively. Two $\mathrm{mL}$ of MUB (Modified Universal Buffer), $\mathrm{pH} 6.5$ for the $\beta$-glucosidase and acid phosphatase assay, and $0.5 \mathrm{~mL}$ of $p$-nitrophenyl substrate ( $p$-nitrophenyl- $\beta$-d-glucopyranoside for $\beta$-glucosidase and $p$-nitrophenyl phosphate for acid phosphatase) were added to $0.5 \mathrm{~g}$ of soil. The mixtures were incubated at $37^{\circ} \mathrm{C}$ for $1 \mathrm{~h}$. Then, the $p$ nitrophenol released was measured at $400 \mathrm{~nm}$ by spectrophotometry. Both activities were expressed in units of micromoles of $p$-nitrophenol (PNP) produced per gram of soil (dry weight) and hour ( $\mu$ mol PNP $\left.\mathrm{g}^{-1} \mathrm{~h}^{-1}\right)$.

\subsection{DNA extraction and amplification}

The DNA was extracted from $400 \mathrm{mg}$ of freeze-dried soil sample using a Fast DNA Spin Kit for soil and the FastPrep Instrument (MP Biomedicals, Santa Ana, CA, USA). The V4 region of bacterial $16 \mathrm{~S}$ ribosomal RNA (rRNA) gene was amplified using the barcoded primers $515 \mathrm{~F}$ and 806R, as described previously (Caporaso et al., 2012). The PCR amplification of the fungal ITS2 region from DNA was performed using barcoded gITS7 and ITS4 (Ihrmark et al., 2012), in three PCR reactions per sample, as described previously (Žifč́áková et al., 2016). The PCR products were cleaned using a MinElute Kit (Qiagen) and their concentrations measured by Qubit. After libraries were prepared, sequencing of fungal and bacterial amplicons was performed on Illumina MiSeq. The amplicon sequencing data were processed using the pipeline SEED2 (Větrovský et al., 2018), as previously described (Žifčáková et al., 2016). Briefly, pair-end reads were merged and whole amplicons of bacterial 16S rRNA gene or the ITS2 regions of fungal amplicons were cleaned of chimeras and clustered into operational taxonomic units (OTUs) at a $97 \%$ similarity level. Consensus sequences were constructed for each cluster, and the closest hits at the genus or species level were identified using BLASTn against the Ribosomal Database Project (Cole et al., 2014) (for bacteria) or UNITE (Koljalg et al., 2014) (for fungi). Sequences identified as non-bacterial or non-fungal were discarded. Low-abundance OTUs, with less than $0.5 \%$ of the sequences 
7 days
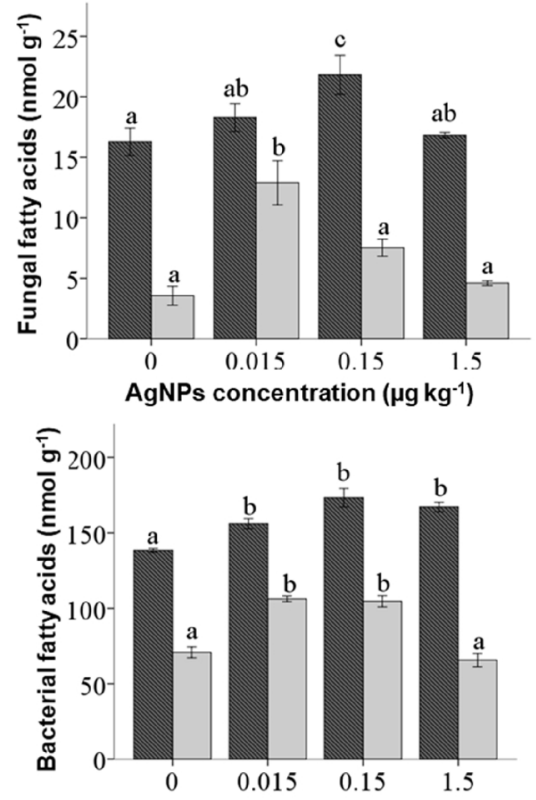

AgNPs concentration $\left(\mu \mathrm{g} \mathrm{kg}^{-1}\right)$
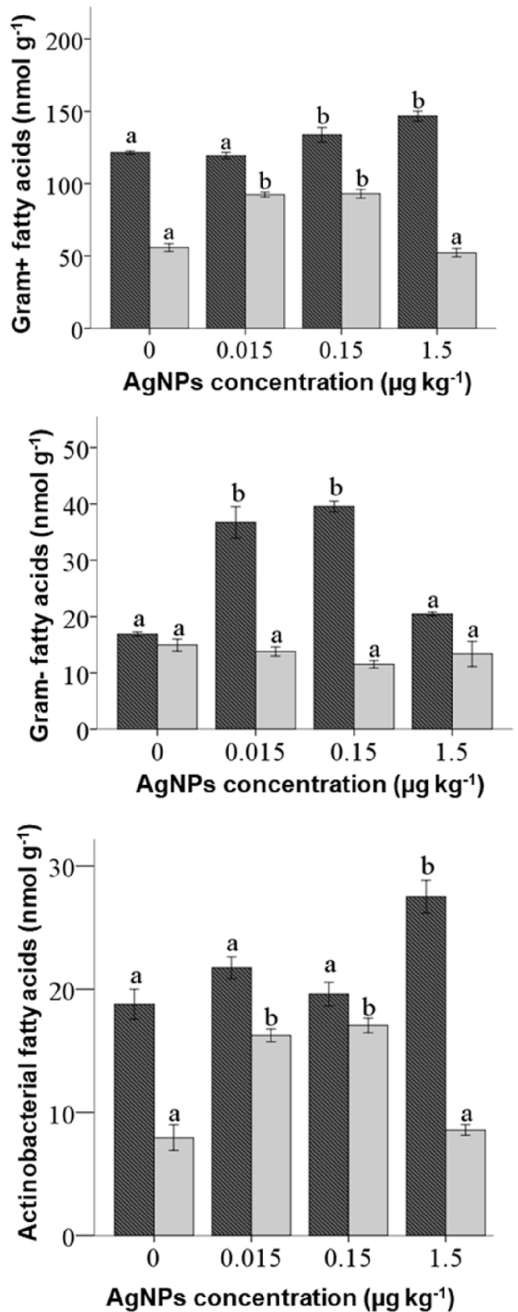

30 days
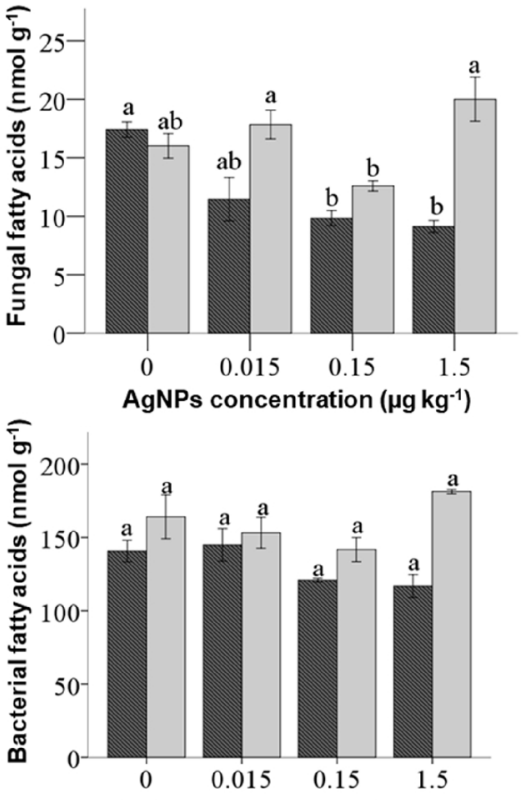

AgNPs concentration ( $\mu \mathrm{g} \mathrm{kg}^{-1}$ )

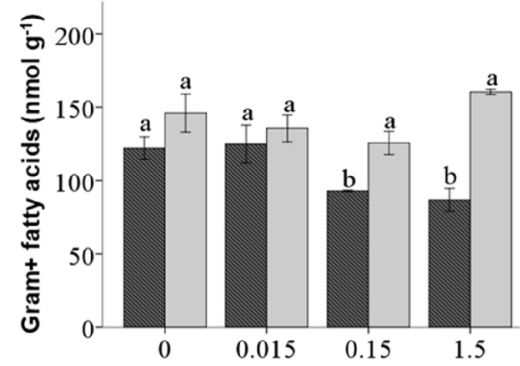

AgNPs concentration ( $\mu \mathrm{g} \mathrm{kg}^{-1}$ )
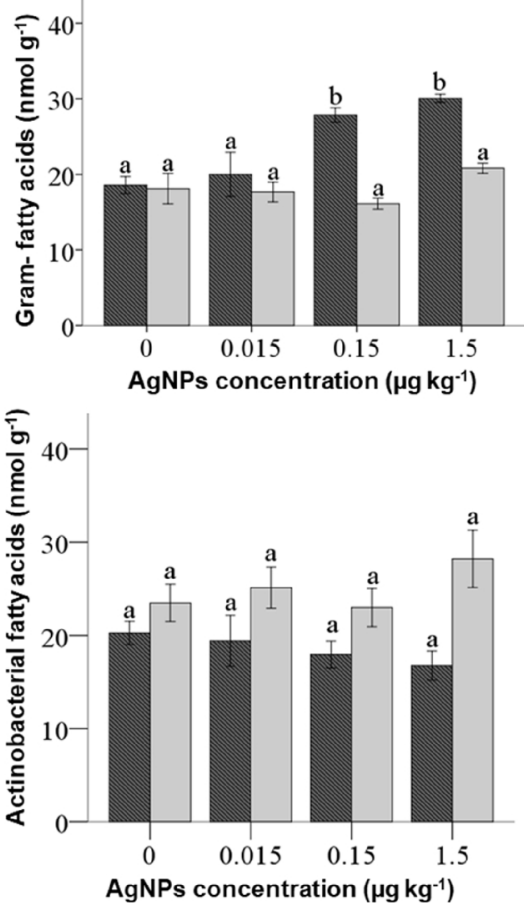

60 days

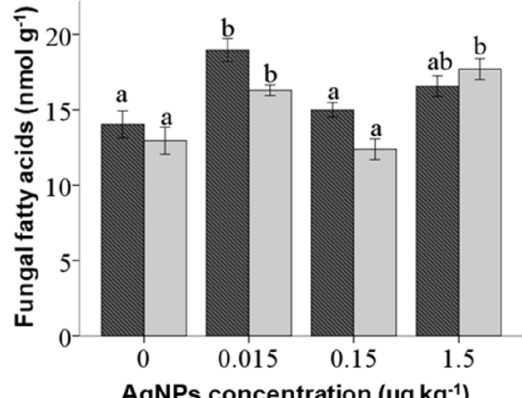

AgNPs concentration ( $\mu \mathrm{g} \mathrm{kg}^{-1}$ )
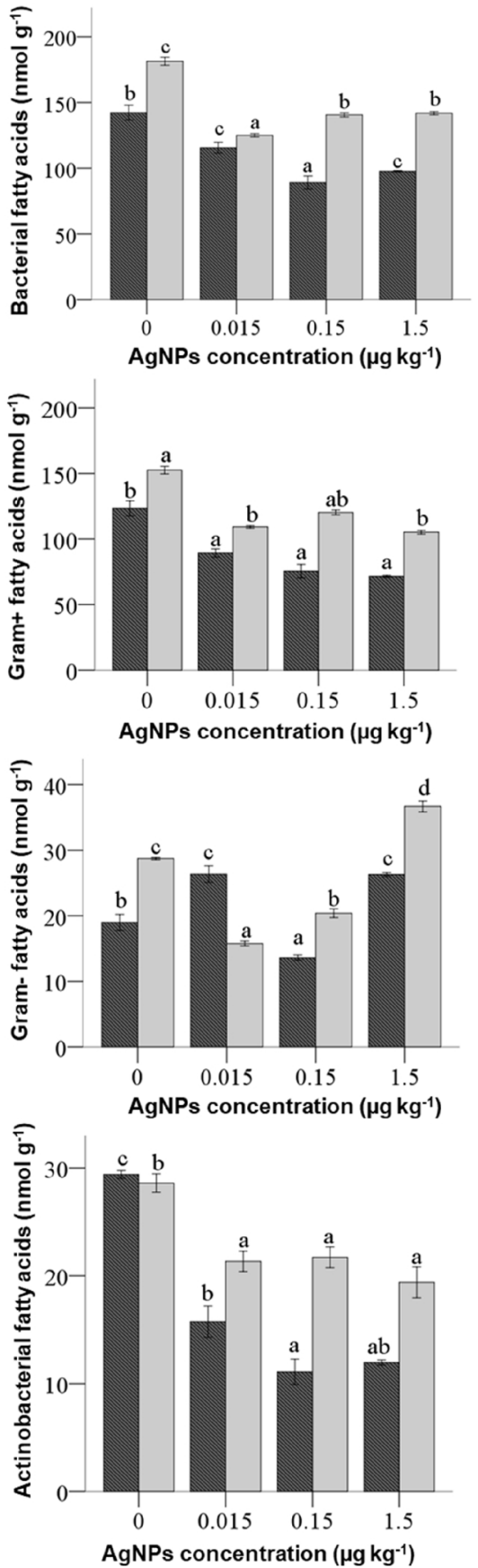

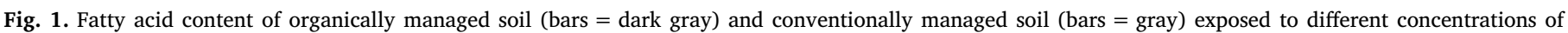

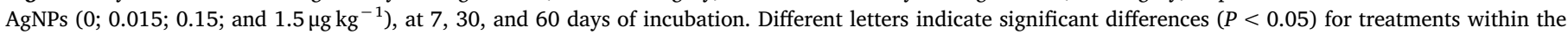

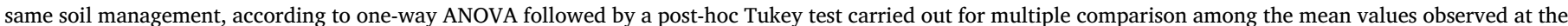
different AgNPs concentrations. 
for fungal and bacterial analyses, were filtered. The pipeline SEED2 was also used for diversity calculations (Větrovský et al., 2018). The DNA sequences have been deposited in the MG-RAST public database with project ID mgp 90907.

\subsection{Data analysis}

The normality and the homogeneity of variances were tested by the Ryan-Joiner and Levene tests, respectively. The variables were subjected to two-way ANOVA. The two factors included in this experimental design were: i) AgNPs concentration, which had 4 levels (0, $0.015,0.15$, and $1.5 \mu \mathrm{g} \mathrm{kg}^{-1}$ ); and ii) soil management, which had two levels (organic soil management, OMS; and conventional soil management, CMS). Further, for each soil management regime, the data were submitted to one-way ANOVA, followed by post hoc analyses using Tukey's significant difference test. Differences at $P<0.05$ were regarded as statistically significant. All results are reported as means \pm standard deviation. These statistical analyses were performed using IBM SPSS (version 20.0; SPSS Inc, Chicago, IL, USA). Principal component analysis (PCA) of the relative abundance of fatty acids for each independent time was performed using PAST 3.22 (Hammer et al., 2001).

The effect of the distinct treatments and types of management on the bacterial and fungal community composition was assessed using PERMANOVA (Anderson, 2001). The Euclidean distance for the Hellinger-transformed bacterial and fungal composition (i.e., a Hellinger distance matrix) (Legendre and Gallagher, 2001) was used as a response matrix and the fixed factors management, treatment, and their interaction were used as explanatory variables. PERMANOVA was performed with adonis function of vegan (Oksanen et al., 2018; R Core Team, 2018). To visualize the results, the Hellinger-transformed community compositions were submitted to PCA and plotted in a biplot that represents the Hellinger distances among sampling units (Legendre and Legendre, 2012). The PCA was performed with the function rda in the vegan package. The analysis was limited to the most abundant species.

\section{Results}

\subsection{Physico-chemical analyses of soil samples}

Relative to the control, we only found a significant reduction $(\mathrm{P}<0.05)$ in the $\mathrm{pH}$ with the highest concentration of AgNPs in the CMS, and in the 0.15 and $1.5 \mu \mathrm{g} \mathrm{kg}^{-1}$ treatments in the OMS, at 7-dayincubation (Table S2). The physico-chemical properties that differ between OMS and CMS were electrical conductivity, pH and WSN (Table S3).

\subsection{Microbial biomass and community structure estimated by fatty acids analysis}

There were differences in microbial biomass, after incubation, between the two types of soil management (conventional and organic) (Table S4). Overall, after 7-day-incubation with AgNPs, we found a statistically significant increase in all the groups of microorganisms estimated by fatty acids analysis in the OMS soil, and an increase in the fungal, bacterial, Gram + , and actinobacterial fatty acids content in the CMS, in a concentration-independent manner (Fig. 1). At 30-day-incubation, bacterial and actinobacterial fatty acids did not change significantly at any AgNPs concentration and any type of soil. In the OMS and AgNPs concentrations of 0.15 and $1.5 \mu \mathrm{kg}^{-1}$, we observed a significant decrease in the fungal and Gram + fatty acids content and a statistically significant increase in the Gram- fatty acid content. However, in the CMS we did not find significant differences in biomass regarding the control. Further, in OMS and CMS at 60-day-incubation, in

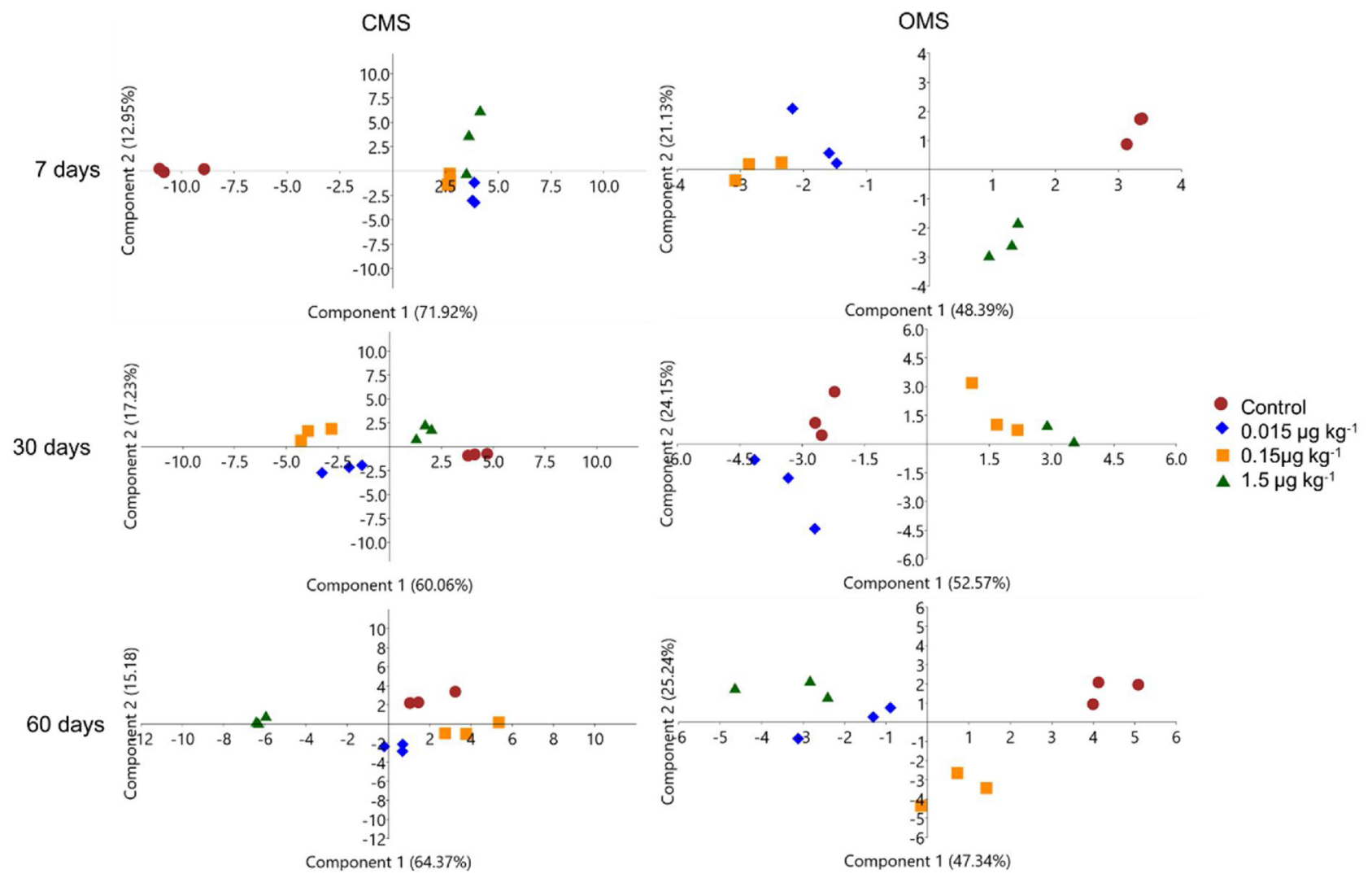

Fig. 2. The principal component analysis (PCA) performed with the relative abundance of fatty acids of organically managed soil (OMS) and conventionally managed soil (CMS) exposed to different concentrations of AgNPs (0; 0.015; 0.15 ; and $\left.1.5 \mu \mathrm{kg}^{-1}\right)$, at 7, 30, and 60 days of incubation. Values in brackets denote the percentage of the data variation explained by a given component. 
all the AgNPs concentrations, there was a significant decrease in the bacterial fatty acid content, including Gram + and actinobacterial representative fatty acids. In contrast, we found an increase in the fungal fatty acid content in the OMS treated with the lowest concentration of AgNPs, and at the concentrations of 0.015 and $1.5 \mu \mathrm{g} \mathrm{kg}^{-1}$ in the CMS. For Gram- representative fatty acids, an increase was found at the 0.015 and $1.5 \mu \mathrm{g} \mathrm{kg}^{-1}$ doses for the OMS, while a decrease at 0.015 and an increase at $1.5 \mu \mathrm{g} \mathrm{kg}^{-1}$ occurred for the CMS (Fig. 1).

The PCA performed with the relative abundance (\%) of fatty acids showed that the AgNPs concentration, exposure time, and soil management influenced the structure of the microbial community (Fig. 2). The first two principal components explained $69-85 \%$ of the observed variance. For the CMS, component 1 clearly differentiated between the control and all AgNPs treatments at 7-day-incubation, and between the highest concentration and all the other treatments at 60-day-incubation. For the OMS, at 7-day-incubation, component 1 differentiated between the control and the low and medium doses; at 30-day-incubation, it differentiated between the medium and high doses; and at 60-day-incubation, the control was separated from all the other treatments.

\subsection{Enzyme activities}

Overall, the $\beta$-glucosidase and urease activities, for all incubation times, were affected significantly by the soil management $(P<0.05)$, but not by the concentration of AgNPs. The phosphatase activity was not affected by the soil management or the AgNPs concentration (Table S4). One-way ANOVA performed separately for each type of soil management confirmed the results of the two-way ANOVA, indicating no significant differences among the soil enzyme activities measured in the different treatments with AgNPs and the unpolluted controls (Table S5).

\subsection{The diversity and composition of the soil microbial community determined through amplicon sequencing}

A PCA of the Hellinger-transformed distances of the bacterial and fungal communities studied through $16 \mathrm{~S}$ rRNA gene and ITS sequencing, respectively, revealed clear differences in the composition of the microbial community between the CMS and OMS, for both the bacterial (PERMANOVA $P$-value $=0.001$ ) and fungal (PERMANOVA $P$ value $=0.001$ ) communities (Fig. $3 \mathrm{~A}$ and $\mathrm{B}$, respectively). However, the impact of the AgNPs on the composition of the soil microbial communities was not significant (PERMANOVA $P$-value $>0.05$ ).

Independently of the AgNPs concentration and the soil

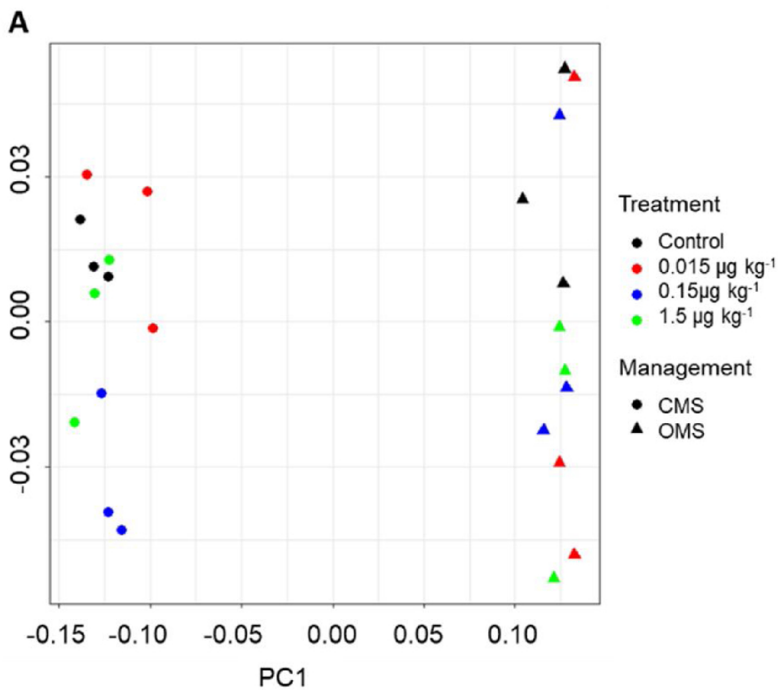

management, the most abundant bacterial phyla were Proteobacteria, Actinobacteria, and Acidobacteria, with up to 39.1, 23.7, and $10.4 \%$ of the sequences, respectively (Fig. 4A). At the genus level, the most abundant taxa were Gaiella, Rhodoplanes, "Candidatus Xiphinematobacter", Conexibacter, and Aciditerrimonas, with up to 7.1, 5.3, 3.6, 3.4, and $3.2 \%$ of the sequences, respectively (Fig. 4B). Overall, differences in the relative abundance of bacterial phyla and genera were not observed among the AgNPs treatments within each soil management type.

The most abundant fungal phylum was Ascomycota, with up to $82.63 \%$ of the sequences. At the genus level, the most abundant taxa in both the CMS and OMS were Mortierella, Fusarium, and Penicillium, with up to $13.99,9.94$, and $6.79 \%$ of the sequences, respectively. The relative abundance of Humicola, Saitozyma, Mortierella, Talaromyces, Staphylotrichum, Pyrenochaetopsis, Neurospora, Chaetosphaeria, Sagenomella, and Metarhizium differed between the OMS and CMS $(P<0.05)$. Some significant differences, within the CMS and OMS, in the relative abundance of fungal populations were observed. In the OMS, the relative abundance of the phylum Mortierellomycota and the genus Mortierella was significantly higher in all the AgNPs treatments than in the control $(P<0.01)$ (Fig. 5A, B). In addition, the relative abundance of the genus Fusarium was significantly lower at the highest concentration of AgNPs compared to the control $(P=0.038)$, and the relative abundance of Fusicolla differed significantly between the lowest AgNPs concentration and the control $(P=0.018)$ (Fig. 5B). Among the samples of the CMS soil receiving AgNPs, the relative abundance of Mortierellomycota and Mortierella was significantly lower at the highest AgNPs concentration than in the control $(P<0.01)$ (Fig. 5A, B).

\section{Discussion}

\subsection{Impact of AgNPs on soil physico-chemical properties and microbial biomass}

Overall, the low - and realistic - AgNPs doses used here did not affect the soil physico-chemical (i.e. electrical conductivity) and chemical properties (i.e. water-soluble $\mathrm{C}$ and $\mathrm{N}$ ) examined, unlike the changes reported in other studies using higher doses of AgNPs (Hänsch and Emmerling, 2010; Antisari et al., 2013). However, we did observe significant impacts of the AgNPs on the soil microbial biomass, which suggests that microbial soil properties might be more sensitive to these AgNPs than soil abiotic properties and that the impact of the AgNPs on the microbial biomass is likely due to their inherent toxicity and biocide effects rather than indirect effects on soil physico-chemical properties. In addition, the impacts of the AgNPs on the soil microbial biomass

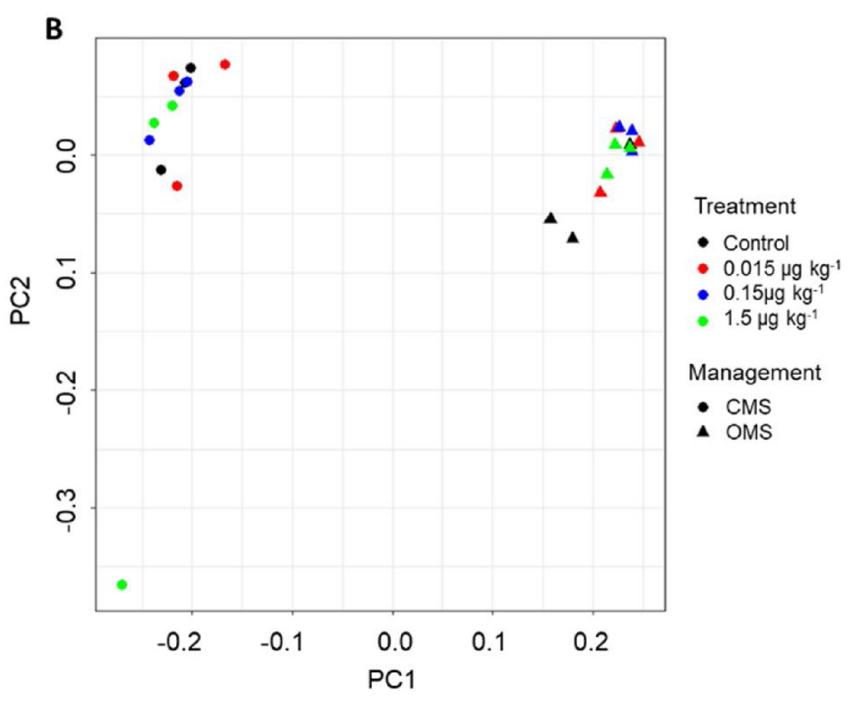

Fig. 3. Principal component analysis (PCA) biplots of the Hellinger-transformed distances of the (A) bacterial and (B) fungal community composition. 
A

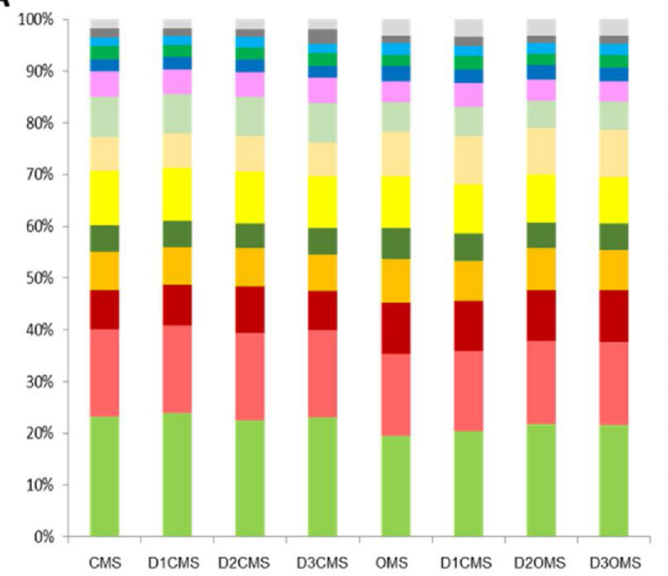

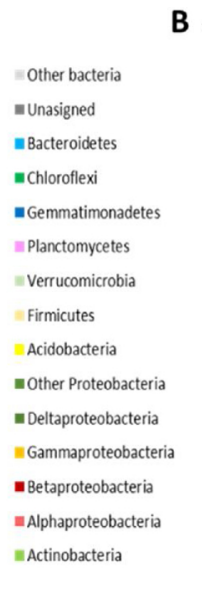

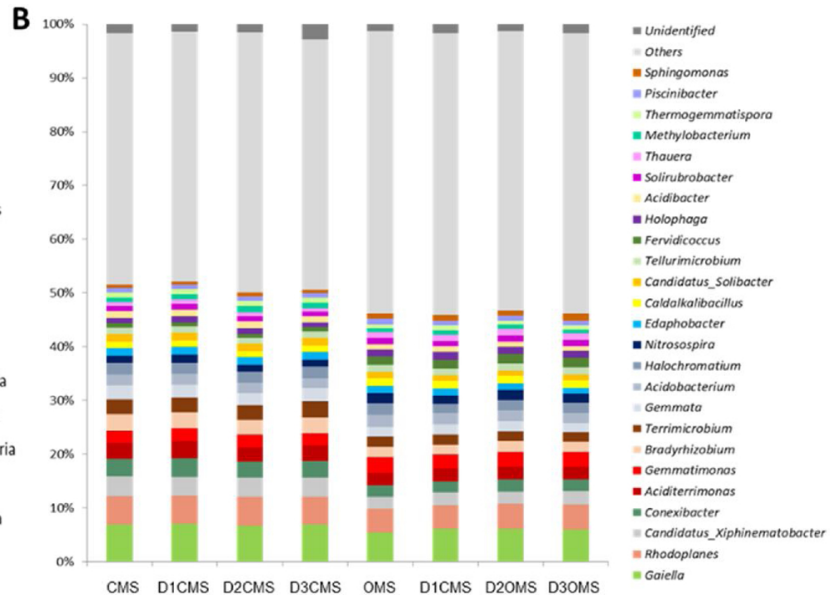

Fig. 4. The composition of the bacterial communities at the phylum/class (A) and genus (B) levels. CMS, D1CMS, D2CMS, and D3CMS are the soil samples with conventional management, corresponding to 0; 0.015; 0.15; and $1.5 \mu \mathrm{g} \mathrm{kg}^{-1}$ AgNPs, respectively. OMS, D1OMS, D2OMS, and D3OMS are the soil samples with organic management, corresponding to $0 ; 0.015 ; 0.15$; and $1.5 \mu \mathrm{kg}^{-1} \mathrm{AgNPs}$, respectively, at 60 days of incubation.

were dependent on the incubation time and the soil management. However, the impact of AgNPs concentration used here was nonlinear, under our experimental conditions. Other studies have found a similar trend, with the concentrations used being less significant in the toxicity of AgNPs than soil texture, silver species, or exposure time (Grün et al., 2018).

When comparing the different incubation times in both types of soil, a decrease in fungal and Gram + biomass was detected at 30-day-incubation in OMS, while in CMS a decrease in bacterial, Gram-, Gram +, and actinobacterial fatty acid content was observed at 60-day-incubation. An enhancement of the toxicity with increasing exposure time has also been highlighted in soils subjected to much higher doses (Schlich and Hund-Rinke, 2015; Tlili et al., 2017; Grün et al., 2018). It was clear that the AgNPs impacts on the two types of soil were different in some microbial groups and at different incubation times. These differences could be attributed to the distinct microbial communities, as OMS had more biomass, enzyme activities and microbial diversity than CMS. Similarly, Sillen et al. (2015) reported that differences in the properties of the soil microbial community, such as biomass and diversity, might result in differences in the impact of AgNPs and the appearance of the effects. Furthermore, the negative impact of the AgNPs on the soil microbial biomass after 60-day-incubation contrasts with the expected protective effect of the high organic matter content in these tropical soils. In detail, it has been suggested that organic matter and clays can complex to AgNPs, reducing their mobility and toxicity (Rahmatpour et al., 2017; Schultz et al., 2018). However, while this protective mechanism could have operated at the beginning of the incubation, the high organic matter content did not protect the bacterial, Gram + and actinobacterial groups, from the harmful impact of the AgNPs in the long term, even at the low and realistic doses assayed here. This lack of protective effect could be due to a slow release of the $\mathrm{Ag}^{+}$ions from the AgNPs complexed to the organic matter and clays, and to the higher toxicity of $\mathrm{Ag}^{+}$when compared to AgNPs, as reported by other authors (Yang et al., 2013; Rahmatpour et al., 2017; Schultz et al., 2018).

More specifically, our results revealed that, at 60-day-incubation, the bacterial biomass was more sensitive to the AgNPs than the fungal biomass, in OMS and CMS. Indeed, fungal and bacterial communities may display varied sensitivities to $\mathrm{Ag}^{+}$(Pshennikova et al., 2011), with eukaryotic cells being more tolerant of $\mathrm{Ag}^{+}$(Kathiresan et al., 2010) and heavy metals (Hiroki, 1992). Several studies have provided evidence for these differences in the responses of bacterial and fungal communities (Kumar and Mamidyala, 2011; Gryndler et al., 2012;
A

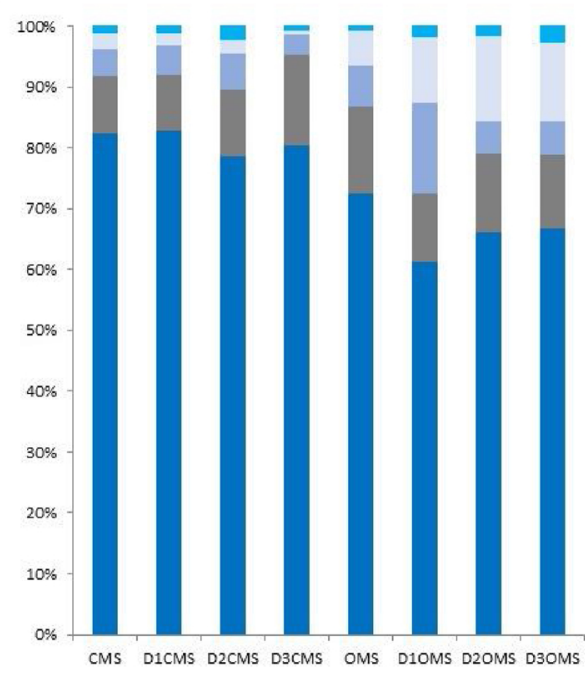

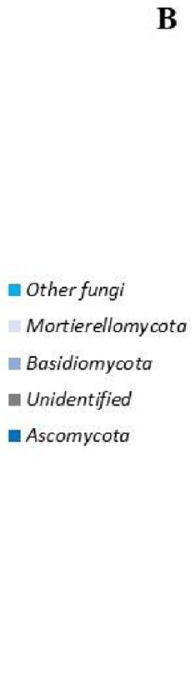

B

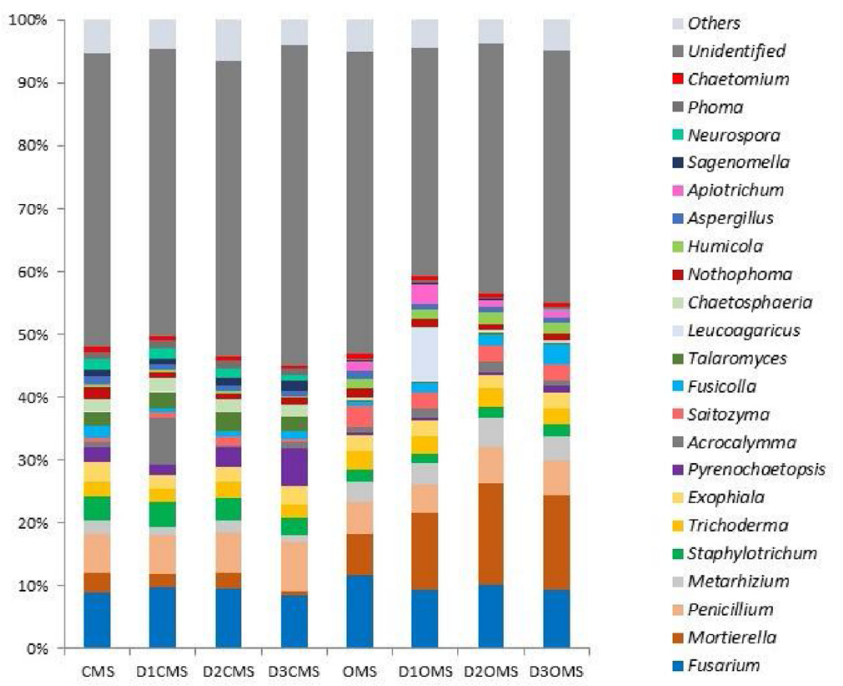

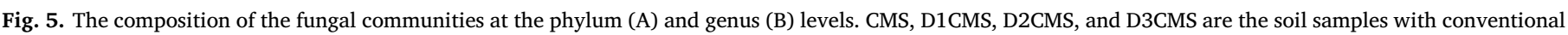

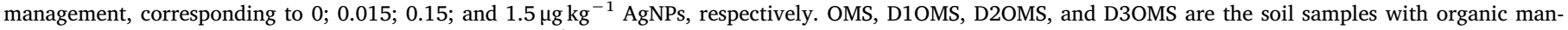
agement, corresponding to 0; 0.015; 0.15; and $1.5 \mu \mathrm{g} \mathrm{kg}^{-1} \mathrm{AgNPs}$, respectively, at 60 days of incubation. 
Sillen et al., 2015). Further, we found that Gram + were more sensitive than Gram- bacteria to the AgNPs. In agreement, Kumar et al. (2014) found a significant reduction in the Gram + bacteria, but not in the Gram-, in an arctic tundra soil treated with $0.066 \%$ and $6.6 \%$ AgNPs. Similarly, Liu et al. (2017) found a decrease in the Gram + bacteria, and an increase in the Gram-, during AgNPs $\left(1 \mathrm{mg} \mathrm{kg}^{-1}\right)$ exposure. This greater resistance of Gram- bacteria can be attributed to the lipopolysaccharides of the outer membrane, which may provide resistance against silver penetration into the cell (Marambio-Jones and Hoek, 2010; Jacobson et al., 2015).

In addition, we found that AgNPs treatments affected the biomass of some microbial groups only in OMS, at 7 and 30-day-incubation. Moreover, in the case of Gram- fatty acids, an opposite response was detected between OMS and CMS at 60 day-incubation. Likewise, other researchers have reported dissimilar responses of different microbial groups to AgNPs, to the point to being species specific (Hänsch and Emmerling, 2010; Pallavi et al., 2016). Furthermore, it has been reported that soil microbial communities can differ in their resistance to AgNPs (Tlili et al., 2017; Asadishad et al., 2018; Grün et al., 2018), due to the presence of sensitive and resistant species, and because some microorganisms can generate tolerance (Samarajeewa et al. 2016). However, further work is needed to study in detail the changes in the microbial community, specially the diversity, and determine which genera and species are responsible for the resistance or tolerance to AgNPs in both soil types. Also, it is important to study the dissolution and aggregation rate of the AgNPs, the organic matter components, and the extracellular polymeric substances in both soils, which can affect the AgNPs toxicity to microorganisms. This knowledge will allow a better understanding of how the changes in the microbial communities can modulate the impact of AgNPs.

\subsection{Impact of AgNPs on enzyme activities}

In general, there was no effect on the enzyme activities ( $\beta$-glucosidase, urease, and acid phosphatase), in both soils, within the range of AgNPs concentrations used in this study. The lack of impact on enzyme activities has been reported previously in studies using higher doses (Colman et al., 2013; Peyrot et al., 2014; Asadishad et al., 2018; Grün et al., 2018). Our results imply that AgNPs affected preferentially the microbial biomass, probably due to the Ag ion released from AgNPs, rather than the extracellular environment (i.e., enzyme activities) (Nannipieri et al., 1990; Burns et al., 2013). It is possible that the high organic matter and clay content, in our soils, contributed to the complexation with AgNPs, and therefore, protected the extracellular enzymes (Burns et al., 2013; Peyrot et al., 2014; Elzobair et al., 2016; Asadishad et al., 2018). In addition, Peyrot et al., 2014 reported that the toxic effect on extracellular enzymes was exerted by the AgNPs instead of ionic Ag, at least at low Ag concentrations. Therefore, the absence of significant differences between AgNPs treatments and the controls, could be related to the stabilization of extracellular enzymes by complex with inorganic surfaces (clay, iron oxides and hydroxides) and adsorption with organic colloids, protecting the enzymes from the AgNPs effects (Nannipieri et al., 2018).

\subsection{Impact of the AgNPs on microbial diversity}

Overall, for both types of soil management, the AgNPs had no significant effect on the composition of the microbial communities, in agreement with other studies that have investigated the effect of medium and high concentrations of AgNPs (Liu et al., 2017; Samarajeewa et al., 2017; Grün et al., 2018). Other researchers have found a similar outcome; for instance, Colman et al. (2013) found no significant differences in the composition of the bacterial community after 50 days of exposure to $0.14 \mathrm{mg} \mathrm{kg}^{-1}$ AgNPs in a forest soil - a dose within the range of our study -. Further, Asadishad et al. (2018) did not find significant differences in the microbial community of an agricultural soil when using $1 \mathrm{mg} \mathrm{kg}^{-1}$ of citrate coated-AgNPs and only found differences at a higher concentration, $100 \mathrm{mg} \mathrm{kg}^{-1}$, much higher than the doses utilized here. Nevertheless, in our work, the AgNPs impacted the relative abundance of some fungal populations. For instance, we found that the AgNPs treatments increased the relative abundance of the phylum Mortierellomycota and the genus Mortierella in the OMS. It has been reported previously that this genus is abundant in natural soils after disturbance because its members may act as decomposers of freshly dead mycelia and bacterial biomass (Brabcová et al., 2018; López-Mondéjar et al., 2018). It can because Mortierella obtains C from simple organic compounds available in soil, like root or hyphal exudates (López-Mondéjar et al., 2018). AgNPs treatments could affect the fungal and bacterial biomass and this may increase the incidence of the opportunistic decomposer Morteriella. In the CMS, we observed a different trend, with a decrease in the Mortierellomycota and the genus Mortierella at the highest dose; this was probably due to differences in the soil management (conventional and organic), because the CMS used fungicides that may decrease the abundance of Mortierella. Also, in the OMS, a decrease in some fungal genera like Fusarium and Fusicolla was detected with the application of AgNPs. Different Fusarium spp. cause recurrent diseases affecting crops worldwide (wheat, barley, oats, rye, and triticale) (Tarazona et al., 2019) and some studies have demonstrated the toxic effect of NPs on different Fusarium spp. (Malandrakis et al., 2019; Tarazona et al., 2019).

\section{Conclusions}

Previous studies using higher doses have opened the door to investigate the impacts of AgNPs in soil, but there was a need to better understand the effects of AgNPs at lower concentrations, similar to those occurring in nature. Our study shows that environmentally relevant concentrations of AgNPs have detrimental effects on the microbial biomass, in a way dependent on the time of exposure and soil management, but independently of the AgNPs concentration. The sensitivity of the biomass of soil microbial groups to AgNPs seems to vary, fungi being more resistant than bacteria and Gram- bacteria more resistant than Gram + . In comparison to their impacts on the soil microbial biomass, the AgNPs had little effect on microbial community composition and on the extracellular soil enzyme activities, which points to a limited impact of silver nanoparticles in soil biogeochemical cycles in a short-term. With this, we state that AgNPs had great impact on soil microbial biomass (studied through fatty acids), but that the effects on the relative abundance of the bacterial dominant organisms are not too selective (studied through DNA sequencing). The results of this research would give to the scientific community the baseline of the effect of realistic concentrations of AgNPs. Future research should address the responses of soil microbial communities and soil physicochemical characteristics to realistic concentrations of AgNPs with different properties (i.e., size, shape, etc.), for a wider variety of soil types and land-uses.

\section{CRediT authorship contribution statement}

Gabriela Montes de Oca-Vásquez: Investigation, Data curation, Writing - original draft, Visualization, Funding acquisition. Frank Solano-Campos: Methodology, Investigation, Resources, Writing - review \& editing, Funding acquisition. José R. Vega-Baudrit: Resources, Writing - review \& editing, Funding acquisition. Rubén LópezMondéjar: Formal analysis, Resources, Data curation, Writing - review \& editing. Iñaki Odriozola: Formal analysis, Resources, Data curation. Alfonso Vera: Investigation, Writing - review \& editing. José L. Moreno: Writing - review \& editing, Funding acquisition. Felipe Bastida: Conceptualization, Methodology, Resources, Writing - review \& editing, Supervision, Funding acquisition. 


\section{Declaration of Competing Interest}

The authors declare that they have no known competing financial interests or personal relationships that could have appeared to influence the work reported in this paper.

\section{Acknowledgements}

This work was supported by the Universidad Nacional (grant number FIDA-0027-17), the National Nanotechnology Laboratory (LANOTEC), scholarships to G.M.V from the National Center for High Technology (CeNAT), and the Costa Rican Ministry of Science, Technology and Telecommunications MICITT, (number FI-014B-18). The authors are grateful to the Agencia Estatal de Investigación(AEI) and the Fondo Europeo de Desarrollo Regional (FEDER) for the project AGL2017-85755-R, the CSIC for the I-LINK + 2018 (LINKA20069) project, and the Fundación Séneca(19896/GERM/15). This study was carried out with permission from the Costa Rican Ministry of Environment and Energy (R-CM-UNA-002-2018-OT). The authors are grateful to Ellen Sancho-Barrantes and Fabián Araya-Yannarella from the Universidad Nacional, for access to the coffee plots and the morphological identification of plants in the study area, respectively.

\section{Appendix A. Supplementary data}

Supplementary material related to this article can be found, in the online version, at doi:https://doi.org/10.1016/j.jhazmat.2020.122224.

\section{References}

Anderson, M.J., 2001. A new method for non-parametric multivariate analysis of variance. Aust. Ecol. 26, 32-46. https://doi.org/10.1111/j.1442-9993.2001.01070.pp.x.

Antisari, L.V., Carbone, S., Gatti, A., Vianello, G., Nannipieri, P., 2013. Toxicity of metal oxide $\left(\mathrm{CeO}_{2}, \mathrm{Fe}_{3} \mathrm{O}_{4}, \mathrm{SnO}_{2}\right)$ engineered nanoparticles on soil microbial biomass and their distribution in soil. Soil Biol. Biochem. 60, 87-94. https://doi.org/10.1016/j. soilbio.2013.01.016.

Arvidsson, R., 2018. Response to comment on "risk assessments show engineered nanomaterials to Be of low environmental concern.". Environ. Sci. Technol. 52, 6725-6726. https://doi.org/10.1021/acs.est.8b02738.

Asadishad, B., Chahal, S., Akbari, A., Cianciarelli, V., Azodi, M., Ghoshal, S., Tufenkji, N., 2018. Amendment of agricultural soil with metal nanoparticles: effects on soil enzyme activity and microbial community composition. Environ. Sci. Technol. 52, 1908-1918. https://doi.org/10.1021/acs.est.7b05389.

Ballottin, D., Fulaz, S., Cabrini, F., Tsukamoto, J., Duran, N., Alves, O.L., Tasic, L., 2017. Antimicrobial textiles: biogenic silver nanoparticles against Candida and Xanthomonas. Mater. Sci. Eng. C 75, 582-589. https://doi.org/10.1016/j.msec.2017. 02.110 .

Bastida, F., Kandeler, E., Moreno, J.L., Ros, M., García, C., Hernández, T., 2008. Application of fresh and composted organic wastes modifies structure, size and activity of soil microbial community under semiarid climate. Appl. Soil Ecol. 40, 318-329. https://doi.org/10.1016/j.apsoil.2008.05.007.

Beddow, J., Stolpe, B., Cole, P.A., Lead, J.R., Sapp, M., Lyons, B.P., Colbeck, I., Whitby, C., 2017. Nanosilver inhibits nitrification and reduces ammonia-oxidising bacterial but not archaeal amoA gene abundance in estuarine sediments. Environ. Microbiol. 19, 500-510. https://doi.org/10.1111/1462-2920.13441.

Bi, Y., Han, B., Zimmerman, S., Perreault, F., Sinha, S., Westerhoff, P., 2018. Four release tests exhibit variable silver stability from nanoparticle-modified reverse osmosis membranes. Water Res. https://doi.org/10.1016/j.watres.2018.06.036.

Brabcová, V., Štursová, M., Baldrian, P., 2018. Nutrient content affects the turnover of fungal biomass in forest topsoil and the composition of associated microbial communities. Soil Biol. Biochem. 118, 187-198. https://doi.org/10.1016/j.soilbio.2017. 12.012 .

Brant, J.B., Myrold, D.D., Sulzman, E.W., 2006. Root controls on soil microbial community structure in forest soils. Oecologia 148, 650-659. https://doi.org/10.1007/ s00442-006-0402-7.

Bundschuh, M., Filser, J., Lüderwald, S., McKee, M.S., Metreveli, G., Schaumann, G.E., Schulz, R., Wagner, S., 2018. Nanoparticles in the environment: where do we come from, where do we go to? Environ. Sci. Eur. 30, 6. https://doi.org/10.1186/s12302018-0132-6.

Burns, R.G., DeForest, J.L., Marxsen, J., Sinsabaugh, R.L., Stromberger, M.E., Wallenstein, M.D., Weintraub, M.N., Zoppini, A., 2013. Soil enzymes in a changing environment: current knowledge and future directions. Soil Biol. Biochem. 58, 216-234. https:// doi.org/10.1016/j.soilbio.2012.11.009.

Camenzind, T., Hättenschwiler, S., Treseder, K.K., Lehmann, A., Rillig, M.C., 2018. Nutrient limitation of soil microbial processes in tropical forests. Ecol. Monogr. 88, 4-21. https://doi.org/10.1002/ecm.1279.
Caporaso, J.G., Lauber, C.L., Walters, W.A., Berg-Lyons, D., Huntley, J., Fierer, N., Owens, S.M., Betley, J., Fraser, L., Bauer, M., Gormley, N., Gilbert, J.A., Smith, G., Knight, R., 2012. Ultra-high-throughput microbial community analysis on the Illumina HiSeq and MiSeq platforms. ISME J. 6, 1621-1624. https://doi.org/10.1038/ismej.2012.8.

Chung, H., Son, Y., Yoon, T.K., Kim, S., Kim, W., 2011. The effect of multi-walled carbon nanotubes on soil microbial activity. Ecotoxicol. Environ. Saf. 74, 569-575. https:// doi.org/10.1016/j.ecoenv.2011.01.004.

Cole, J.R., Wang, Q., Fish, J.A., Chai, B., McGarrell, D.M., Sun, Y., Brown, C.T., PorrasAlfaro, A., Kuske, C.R., Tiedje, J.M., 2014. Ribosomal Database Project: data and tools for high throughput rRNA analysis. Nucleic Acids Res. 42, 633-642. https://doi. org/10.1093/nar/gkt1244.

Colman, B.P., Arnaout, C.L., Anciaux, S., Gunsch, C.K., Hochella, M.F., Kim, B., Lowry, G.V., McGill, B.M., Reinsch, B.C., Richardson, C.J., Unrine, J.M., Wright, J.P., Yin, L., Bernhardt, E.S., 2013. Low concentrations of silver nanoparticles in biosolids cause adverse ecosystem responses under realistic field scenario. PLoS One 8. https://doi. org/10.1371/journal.pone.0057189.

Delgado-Baquerizo, M., Maestre, F.T., Reich, P.B., Jeffries, T.C., Gaitan, J.J., Encinar, D., Berdugo, M., Campbell, C.D., Singh, B.K., 2016. Microbial diversity drives multifunctionality in terrestrial ecosystems. Nat. Commun. 7, 10541. https://doi.org/10. 1038/ncomms10541.

Dungait, J.A.J., Kemmitt, S.J., Michallon, L., Guo, S., Wen, Q., Brookes, P.C., Evershed, R.P., 2011. Variable responses of the soil microbial biomass to trace concentrations of ${ }^{13} \mathrm{C}$-labelled glucose, using ${ }^{13} \mathrm{C}$-PLFA analysis. Eur. J. Soil Sci. $62,117-126$. https:// doi.org/10.1111/j.1365-2389.2010.01321.x.

Eivazi, F., Tabatabai, M.A., 1977. Phosphatases in soils. Soil Biol. Biochem. 9, 167-172. https://doi.org/10.1016/0038-0717(77)90070-0.

Elzobair, K.A., Stromberger, M.E., Ippolito, J.A., 2016. Stabilizing effect of biochar on soil extracellular enzymes after a denaturing stress. Chemosphere 142, 114-119. https:// doi.org/10.1016/j.chemosphere.2015.03.018.

Frostegård, Å., Bååth, E., Tunlio, A., 1993. Shifts in the structure of soil microbial communities in limed forests as revealed by phospholipid fatty acid analysis. Soil Biol. Biochem. 25, 723-730. https://doi.org/10.1016/0038-0717(93)90113-P.

García-Delgado, C., Barba-Vicente, V., Marín-Benito, J.M., Igual, J.M., Sánchez-Martín, M.J., Rodríguez-Cruz, M.S., 2019. Influence of different agricultural management practices on soil microbial community over dissipation time of two herbicides. Sci. Total Environ. 646, 1478-1488. https://doi.org/10.1016/j.scitotenv.2018.07.395.

Giese, B., Klaessig, F., Park, B., Kaegi, R., Steinfeldt, M., 2018. Risks, release and concentrations of engineered nanomaterial in the environment. Sci. Rep. 1-18. https:// doi.org/10.1038/s41598-018-19275-4.

Gottschalk, F., Sonderer, T., Scholz, R.W., Nowack, B., 2010. Possibilities and limitations of modeling environmental exposure to engineered nanomaterials by probabilistic material flow analysis. Environ. Toxicol. Chem. 29, 1036-1048. https://doi.org/10. 1002/etc.135.

Graham, E.B., Knelman, J.E., Schindlbacher, A., Siciliano, S., Breulmann, M., Yannarell, A., Beman, J.M., Abell, G., Philippot, L., Prosser, J., 2016. Microbes as engines of ecosystem function: when does community structure enhance predictions of ecosystem processes? Front. Microbiol. 7, 214. https://doi.org/10.3389/fmicb.2016. 00214.

Grün, A., Straskraba, S., Schulz, S., Schloter, M., Emmerling, C., 2018. Long-term effects of environmentally relevant concentrations of silver nanoparticles on microbial biomass, enzyme activity, and functional genes involved in the nitrogen cycle of loamy soil. J. Environ. Sci. 1-11. https://doi.org/10.1016/j.jes.2018.04.013.

Grün, A.L., Manz, W., Kohl, Y.L., Meier, F., Straskraba, S., Jost, C., Drexel, R., Emmerling, C., 2019. Impact of silver nanoparticles (AgNP) on soil microbial community depending on functionalization, concentration, exposure time, and soil texture. Environ. Sci. Eur. 31, 15. https://doi.org/10.1186/s12302-019-0196-y.

Gryndler, M., Hršelová, H., Soukupová, L., Borovička, J., 2012. Silver release from decomposed hyperaccumulating Amanita solitaria fruit-body biomass strongly affects soil microbial community. Biometals 25, 987-993. https://doi.org/10.1007/s10534012-9564-4.

Hammer, Ø., Harper, D., Ryan, P., 2001. Past: paleontological statistics software package for education and data analysis. Paleontol. Electron. 4, 1-9.

Hänsch, M., Emmerling, C., 2010. Effects of silver nanoparticles on the microbiota and enzyme activity in soil. J. Plant Nutr. Soil Sci. 173, 554-558. https://doi.org/10. 1002/jpln.200900358.

Haq, I.U., Ijaz, S., 2019. Use of metallic nanoparticles and nanoformulations as nanofungicides for sustainable disease management in plants. Nanobiotechnology in Bioformulations. Springer, pp. 289-316. https://doi.org/10.1007/978-3-030-17061512.

Hiroki, M., 1992. Effects of heavy metal contamination on soil microbial population. Soil Sci. Plant Nutr. 38, 141-147. https://doi.org/10.1080/00380768.1992.10416961.

Ihrmark, K., Bödeker, I.T.M., Cruz-Martinez, K., Friberg, H., Kubartova, A., Schenck, J. Strid, Y., Stenlid, J., Brandström-Durling, M., Clemmensen, K.E., Lindahl, B.D., 2012. New primers to amplify the fungal ITS2 region - evaluation by 454-sequencing of artificial and natural communities. FEMS Microbiol. Ecol. 82, 666-677. https://doi. org/10.1111/j.1574-6941.2012.01437.x.

Instituto del Café de Costa Rica, 2019. Informe de la actividad cafetalera de Costa Rica 2019. Retrieved from. http://www.icafe.cr/sector-cafetalero/informacion-demercado/informes-de-la-actividad-cafetalera/.

Jacobson, K.H., Gunsolus, I.L., Kuech, T.R., Troiano, J.M., Melby, E.S., Lohse, S.E., Hu, D., Chrisler, W.B., Murphy, C.J., Orr, G., Geiger, F.M., Haynes, C.L., Pedersen, J.A., 2015. Lipopolysaccharide density and structure govern the extent and distance of nanoparticle interaction with actual and model bacterial outer membranes. Environ. Sci. Technol. 49, 10642-10650. https://doi.org/10.1021/acs.est.5b01841.

Kandeler, E., Gerber, H., 1988. Short-term assay of soil urease activity using colorimetric determination of ammonium. Biol. Fertil. Soils 6, 68-72. https://doi.org/10.1007/ 
BF00257924.

Kathiresan, K., Alikunhi, N.M., Pathmanaban, S., Nabikhan, A., Kandasamy, S., 2010. Analysis of antimicrobial silver nanoparticles synthesized by coastal strains of Escherichia coli and Aspergillus niger. Can. J. Microbiol. 56, 1050-1059. https://doi. org/10.1139/W10-094.

Koljalg, U., Nilsson, R.H., Abarenkov, K., Tedersoo, L., Taylor, A.F.S., Bahram, M., 2014. Towards a unified paradigm for sequence-based identification of fungi. Mol. Ecol. 22, 5271-5277. https://doi.org/10.1111/mec.12481.

Kraas, M., Schlich, K., Knopf, B., Wege, F., Kägi, R., Terytze, K., Hund-Rinke, K., 2017. Long-term effects of sulfidized silver nanoparticles in sewage sludge on soil microflora. Environ. Toxicol. Chem. 36, 3305-3313. https://doi.org/10.1002/etc.3904.

Kumar, C.G., Mamidyala, S.K., 2011. Extracellular synthesis of silver nanoparticles using culture supernatant of Pseudomonas aeruginosa. Colloids Surf. B Biointerfaces 84 , 462-466. https://doi.org/10.1016/j.colsurfb.2011.01.042.

Kumar, N., Palmer, G.R., Shah, V., Walker, V.K., 2014. The effect of silver nanoparticles on seasonal change in arctic tundra bacterial and fungal assemblages. PLoS One 9. https://doi.org/10.1371/journal.pone.0099953.

Kumar, S., Shukla, A., Pratim, P., Mitra, A., Halder, D., 2018. Biodegradable hybrid nanocomposites of chitosan/gelatin and silver nanoparticles for active food packaging applications. Food Packag. Shelf Life 16, 178-184. https://doi.org/10.1016/j.fpsl. 2018.03.008.

Legendre, P., Gallagher, E.D., 2001. Ecologically meaningful transformations for ordination of species data. Oecologia 129, 271-280. https://doi.org/10.1007/ s004420100716.

Legendre, P., Legendre, L.F.J., 2012. Numerical Ecology. Elsevier.

Liu, G., Zhang, M., Jin, Y., Fan, X., Xu, J., 2017. The effects of low concentrations of silver nanoparticles on wheat growth, seed quality, and soil microbial communities. Water Air Soil Pollut. 228, 1-12. https://doi.org/10.1007/s11270-017-3523-1.

López-Mondéjar, R., Brabcová, V., Štursová, M., Davidová, A., Jansa, J., Cajthaml, T., Baldrian, P., 2018. Decomposer food web in a deciduous forest shows high share of generalist microorganisms and importance of microbial biomass recycling. ISME J. 12, 1768-1778. https://doi.org/10.1038/s41396-018-0084-2.

Malandrakis, A.A., Kavroulakis, N., Chrysikopoulos, C.V., 2019. Use of copper, silver and zinc nanoparticles against foliar and soil-borne plant pathogens. Sci. Total Environ. 670, 292-299. https://doi.org/10.1016/j.scitotenv.2019.03.210.

Marambio-Jones, C., Hoek, E.M.V., 2010. A review of the antibacterial effects of silver nanomaterials and potential implications for human health and the environment. J. Nanopart. Res. 12, 1531-1551. https://doi.org/10.1007/s11051-010-9900-y.

Matsuhisa, N., Inoue, D., Zalar, P., Jin, H., Matsuba, Y., Itoh, A., Yokota, T., Hashizume, D., Someya, T., 2017. Printable elastic conductors by in situ formation of silver nanoparticles from silver flakes. Nat. Mater. 16, 834. https://doi.org/10.1038/ nmat4904.

McGee, C.F., Storey, S., Clipson, N., Doyle, E., 2017. Soil microbial community responses to contamination with silver, aluminium oxide and silicon dioxide nanoparticles. Ecotoxicology 26, 449-458. https://doi.org/10.1007/s10646-017-1776-5.

McGee, C.F., Storey, S., Clipson, N., Doyle, E., 2018. Concentration-dependent responses of soil bacterial, fungal and nitrifying communities to silver nano and micron particles. Environ. Sci. Pollut. Res. 25, 18693-18704. https://doi.org/10.1007/s11356018-2087-y.

McKee, M.S., Filser, J., 2016. Impacts of metal-based engineered nanomaterials on soil communities. Environ. Sci. Nano 3, 506-533. https://doi.org/10.1039/c6en00007j.

Moreno, J.L., Torres, I.F., García, C., López-Mondéjar, R., Bastida, F., 2019. Land use shapes the resistance of the soil microbial community and the $\mathrm{C}$ cycling response to drought in a semi-arid area. Sci. Total Environ. 648, 1018-1030. https://doi.org/10. 1016/j.scitotenv.2018.08.214.

Nannipieri, P., Grego, S., Ceccanti, B., Bollag, J., Stotzky, G., 1990. Ecological significance of the biological activity in soil. Soil Biochemistry.

Nannipieri, P., Trasar-Cepeda, C., Dick, R.P., 2018. Soil enzyme activity: a brief history and biochemistry as a basis for appropriate interpretations and meta-analysis. Biol. Fertil. Soils 54, 11-19. https://doi.org/10.1007/s00374-017-1245-6.

Oksanen, J., Blanchet, F.G., Friendly, M., Kindt, R., Legendre, P., McGlinn, D., Minchin, P.R., O’Hara, R.B., Simpson, G.L., Solymos, P., 2018, vegan: Community Ecology Package. R package version 2.5-2. 2018.

Pallavi, Mehta, C.M, Srivastava, R., Arora, S., Sharma, A.K., 2016. Impact assessment of silver nanoparticles on plant growth and soil bacterial diversity. 3 Biotech 6, 1-10. https://doi.org/10.1007/s13205-016-0567-7.

Peyrot, C., Wilkinson, K.J., Desrosiers, M., Sauvé, S., 2014. Effects of silver nanoparticles on soil enzyme activities with and without added organic matter. Environ. Toxicol Chem. 33, 115-125. https://doi.org/10.1002/etc.2398.

Pshennikova, E.S., Filippovich, S.Y., Bachurina, G.P., Ponomareva, V.D., Malygin, A.G., 2011. The different effects of carbon dioxide on the toxicity of silver ions for prokaryotic and eukaryotic microorganisms. Biol. Bull. 38, 297-300. https://doi.org/10. 1134/S1062359011030113.

R Core Team, 2018. R: a Language and Environment for Statistical Computing. URL. R Foundation for Statistical Computing, Vienna, Austria. https://www.r-project.org/.

Raffi, M.M., Husen, A., 2019. Impact of fabricated nanoparticles on the rhizospheric microorganisms and soil environment. Nanomaterials and Plant Potential. Springer, pp. 529-552. https://doi.org/10.1007/978-3-030-05569-1_21.

Rahmatpour, S., Shirvani, M., Mosaddeghi, M.R., Nourbakhsh, F., Bazarganipour, M.,
2017. Dose-response effects of silver nanoparticles and silver nitrate on microbial and enzyme activities in calcareous soils. Geoderma 285, 313-322. https://doi.org/ 10.1016/j.geoderma.2016.10.006.

Rinnan, R., Bååth, E., 2009. Differential utilization of carbon substrates by bacteria and fungi in tundra soil. Appl. Environ. Microbiol. 75, 3611-3620. https://doi.org/10. 1128/AEM.02865-08.

Salvioni, L., Galbiati, E., Collico, V., Alessio, G., Corsi, F., Tortora, P., Prosperi, D., Colombo, M., 2017. Negatively charged silver nanoparticles with potent antibacterial activity and reduced toxicity for pharmaceutical preparations. Int. J. Nanomed. 2517-2530. https://doi.org/10.2147/IJN.S127799.

Samarajeewa, A.D., Velicogna, J.R., Princz, J.I., Subasinghe, R.M., Scroggins, R.P., Beaudette, L.A., 2017. Effect of silver nano-particles on soil microbial growth, activity and community diversity in a sandy loam soil. Environ. Pollut. 220, 504-513. https://doi.org/10.1016/j.envpol.2016.09.094.

Schlich, K., Hund-Rinke, K., 2015. Influence of soil properties on the effect of silver nanomaterials on microbial activity in five soils. Environ. Pollut. 196, 321-330. https:// doi.org/10.1016/j.envpol.2014.10.021.

Schultz, C.L., Lahive, E., Lawlor, A., Crossley, A., Puntes, V., Unrine, J.M., Svendsen, C., Spurgeon, D.J., 2018. Influence of soil porewater properties on the fate and toxicity of silver nanoparticles to Caenorhabditis elegans. Environ. Toxicol. Chem. 37 , 2609-2618. https://doi.org/10.1002/etc.4220.

Schutter, M.E., Dick, R.P., 2000. Comparison of fatty acid methyl ester (FAME) methods for characterizing microbial communities. Soil Sci. Soc. Am. J. 64, 1659. https://doi. org/10.2136/sssaj2000.6451659x.

Shen, J., Chen, C.R., Lewis, T., 2016. Long term repeated fire disturbance alters soil bacterial diversity but not the abundance in an Australian wet sclerophyll forest. Nat. Publ. Gr. 1-10. https://doi.org/10.1038/srep19639.

Shin, Y.J., Kwak II, J., An, Y.J., 2012. Evidence for the inhibitory effects of silver nanoparticles on the activities of soil exoenzymes. Chemosphere 88, 524-529. https://doi. org/10.1016/j.chemosphere.2012.03.010.

Sillen, W.M.A., Thijs, S., Abbamondi, G.R., Janssen, J., Weyens, N., White, J.C., Vangronsveld, J., 2015. Effects of silver nanoparticles on soil microorganisms and maize biomass are linked in the rhizosphere. Soil Biol. Biochem. 91, 14-22. https:// doi.org/10.1016/j.soilbio.2015.08.019.

Simonin, M., Richaume, A., 2015. Impact of engineered nanoparticles on the activity, abundance, and diversity of soil microbial communities: a review. Environ. Sci. Pollut. Res. 22, 13710-13723. https://doi.org/10.1007/s11356-015-4171-x.

Smith, P., House, J.I., Bustamante, M., Sobocká, J., Harper, R., Pan, G., West, P.C., Clark, J.M., Adhya, T., Rumpel, C., 2016. Global change pressures on soils from land use and management. Glob. Change Biol. 22, 1008-1028. https://doi.org/10.1111/gcb. 13068.

Storey, C.F.M.S., Doyle, N.C.E., 2017. Soil microbial community responses to con tamination with silver, aluminium oxide and silicon dioxide nanoparticles. Ecotoxicology 1-9. https://doi.org/10.1007/s10646-017-1776-5.

Tabatabai, M.A., Bremner, J.M., 1969. Use of p-nitrophenyl phosphate for assay of soil phosphatase activity. Soil Biol. Biochem. 1, 301-307. https://doi.org/10.1016/00380717(69)90012-1.

Tarazona, A., Gómez, J.V., Mateo, E.M., Jiménez, M., Mateo, F., 2019. Antifungal effect of engineered silver nanoparticles on phytopathogenic and toxigenic Fusarium spp. And their impact on mycotoxin accumulation. Int. J. Food Microbiol. 306, 108259. https://doi.org/10.1016/j.ijfoodmicro.2019.108259.

Tlili, A., Jabiol, J., Behra, R., Gil-Allué, C., Gessner, M.O., 2017. Chronic exposure effects of silver nanoparticles on stream microbial decomposer communities and ecosystem functions. Environ. Sci. Technol. 51, 2447-2455. https://doi.org/10.1021/acs.est. 6 b05508.

van Hengel, I.A.J., Riool, M., Fratila-Apachitei, L.E., Witte-Bouma, J., Farrell, E., Zadpoor, A.A., Zaat, S.A.J., Apachitei, I., 2017. Selective laser melting porous metallic implants with immobilized silver nanoparticles kill and prevent biofilm formation by methicillin-resistant Staphylococcus aureus. Biomaterials 140, 1-15. https://doi.org/10. 1016/j.biomaterials.2017.02.030.

Větrovský, T., Baldrian, P., Morais, D., 2018. SEED 2: a user-friendly platform for amplicon high-throughput sequencing data analyses. Bioinformatics 34, 2292-2294. https://doi.org/10.1093/bioinformatics/bty071.

Wang, P., Menzies, N.W., Dennis, P.G., Guo, J., Forstner, C., Sekine, R., Lombi, E., Kappen, P., Bertsch, P.M., Kopittke, P.M., 2016. Silver nanoparticles entering soils via the wastewater- sludge-soil pathway pose low risk to plants but elevated $\mathrm{Cl}$ concentrations increase Ag bioavailability. Environ. Sci. Technol. 50. https://doi.org/10. 1021/acs.est.6b01180.

Yang, Y., Wang, J., Xiu, Z., Alvarez, P.J.J., 2013. Impacts of silver nanoparticles on cellular and transcriptional activity of nitrogen-cycling bacteria. Environ. Toxicol. Chem. 32, 1488-1494. https://doi.org/10.1002/etc.2230.

Žifčáková, L., Větrovský, T., Howe, A., Baldrian, P., 2016. Microbial activity in forest soil reflects the changes in ecosystem properties between summer and winter. Environ. Microbiol. 18, 288-301. https://doi.org/10.1111/1462-2920.13026.

Zornoza, R., Acosta, J.A., Martínez-Martínez, S., Faz, A., Bååth, E., 2015. Main factors controlling microbial community structure and function after reclamation of a tailing pond with aided phytostabilization. Geoderma 245, 1-10. https://doi.org/10.1016/j. geoderma.2015.01.007. 